\title{
Research on Practice Teaching System of Marketing Major under Modern Apprenticeship Mode
}

\author{
Ling Li \\ Shan Dong Huayu University of Technology, Shan Dong, China, 253034
}

Keywords: modern apprenticeship mode; marketing major; teaching system

\begin{abstract}
Modern apprenticeship is a mode of talent cultivation to cultivate talents that meet the requirements of enterprises, which is widely used in practical teaching of marketing and has trained a large number of professional talents for the marketing industry. This paper expounds the application of modern apprenticeship in marketing professional practice teaching, analyzes the difficulties of modern marketing apprenticeship system under the professional apprenticeship model, and proposes relative countermeasures for the establishment of the marketing professional practice teaching system.
\end{abstract}

\section{Introduction}

Modern apprenticeship is a product of market economy and social economic development, which has social and economical characteristics. The reasonable application of modern apprenticeship to the practice teaching of marketing specialty will not only beneficial to the improvement of the teaching quality and efficiency of the marketing major, but also conducive to the improvement and innovation of the teaching system of marketing specialized industry. It is the transfer of students from the school to the school. Modern apprenticeship is the key measure for students to shift from study to work. It is the transition zone between school education and employment, which means, from school to apprenticeship, and from apprenticeship to employment is the best way for students to adapt to the social and job positions. In fact, no matter how experienced the enterprise is, and how many theories student have, the students always need a transition period from school to social work, but the transition period is different in different training modes. The transition period of practice teaching under the modern apprenticeship system is the shortest. Therefore, we should strengthen the construction of the marketing professional practice teaching system so as to improve the quality and efficiency of marketing teaching, and help improve students' practical ability, adaptability and survivability.

\section{The Application of Modern Apprenticeship Model}

\subsection{Application prerequisites}

The first is the professional ability of higher vocational teachers. Under the constraints of scientific research rankings, teaching competitions, and job title evaluation systems, the threshold of job candidates for higher vocational colleges is increasing year by year [1]. The higher vocational colleges pay more attention to the applicant's education background while ignoring the applicant's industry experience. However, the obstacle is that teachers are struggling to cope with the assessment of various teaching tasks. It is difficult for them to enter the company's frontline to practice practical skills as a part-time job. On the other side, the first-line workers of the company have strong practical abilities and rich working experience, but they do not have enough teaching experience to effectively communicate skills and technology to students. Therefore, the professional ability of higher vocational teachers plays a critical role in the implementation of modern apprenticeship. Schools should implement the teacher's corporate practice system, help teachers to get into production training as much as possible, thus to form the practical teaching wisdom in practice.

Second is the industry guidance and service. As industry associations are different from ordinary 
social organizations and have mastered the latest and most complete information data in the industry, they have professional judgments on the company's technical requirements and talent needs. Therefore, it is required that each industry association establishes a vocational education committee to be responsible for the formulation of professional standards for vocational education and assessment of qualifications for practice. However, the industry associations play a very limited role in the development of vocational education in our country, and the standards for cultivating talents in various schools are not uniform, resulting in students who are not trained to make them satisfied. Therefore, in the process of promoting modern apprenticeship, industry associations need to have a clearer role orientation, to guide education and teaching, and provide industry human resources demand forecast and employment information for the training of the talents in the school, and to solve the problem of information asymmetry between the market and the schools.

\subsection{Necessity of implementing modern apprenticeship model}

The development of marketing majors in higher vocational colleges has generally experienced the investment from the emphasis on practical teaching to the emphasis on the construction of practical training bases, and has been exploring the teaching of professional skills for many years [2]. Although a lot of efforts and attempts have been made, only a few sets of sand tray practical training software, single practical training projects, practice teaching combined with the combination of competition and teaching, and organized students' internship in a period of time, can only solve the problems in one aspect of the work temporarily, and cannot fully meet the requirements of the enterprises. Neither the practical teaching experience of teachers nor the update speed of training conditions can meet the requirements of the market. The complex comprehensive ability of skilled talents can only be obtained in the actual working situation and the whole process of work. The modern apprenticeship is undoubtedly a good medicine to solve this problem.

\section{The Problems to be Solved in Building a Practice Teaching System Based on Modern Apprenticeship Model}

\subsection{To strive for the active promotion of the industry}

The industry has an irreplaceable role in formulating relevant industry standards for modern apprenticeships. Therefore, to create a successful modern apprenticeship talent training model and construct a practice teaching system based on marketing apprenticeship in modern apprenticeship, it must enable the Marketing Institute to make a strong push for modern apprenticeships.

\subsection{To get strong supports from enterprises}

From the successful experience of the modern apprenticeship system in Germany, Britain, and Australia, it can be seen that the strong support of the enterprise is the power that must be acquired in the process of constructing a practice teaching system based on marketing apprenticeship in modern apprenticeship. Otherwise, the apprenticeship cannot be implemented successfully.

\subsection{To build strong faculty as powerful guarantee}

In modern apprenticeship, the strength of teachers is a powerful guarantee for the successful implementation of modern apprenticeship, which determines the final quality of the apprentice. Therefore, a strong faculty is one of the essential elements of modern apprenticeship in marketing.

\subsection{To establish a perfect modern apprenticeship organization}

Through the successful implementation of the modern apprenticeship system in foreign countries, it can be conclude that any country and major who successfully implement the modern apprenticeship has a perfect organization of modern apprenticeship, which includes financial institutions, certification bodies, regulatory agencies, and industry institutions related to apprenticeship. Only when these organizations form a relatively perfect organization and management system with government departments, can the development of modern apprenticeship be vigorously promoted. 


\section{The Construction of Practice Teaching System of Marketing Major under Modern Apprenticeship Model}

\subsection{Establish practice training concept for marketing major}

With the continuous development of the market economy, the demand for marketing professionals from the society and enterprises has been increasing, which leading to the marketing talents cultivated by schools cannot meet the needs of the enterprises. In order to improve the quality of marketing teaching and meet the needs of society and enterprises, we should implement modern apprenticeship actively. In the implementation process, modern apprenticeship requires that the personnel be trained to change their own practice training concepts and give the students or apprentices the dominant position of teaching or training. Therefore, we should actively establish the practice training concept of marketing specialty. The core of this concept is to cultivate applied talents, which is embodied in the following two aspects. First is to cultivate marketing talents with professional marketing theory knowledge and high practical ability. Secondly, since marketing students should have the comprehensive ability of school professional foundation and enterprise application characteristics. Therefore, the training goal is to cultivate students into applied marketing professionals.

\subsection{Construct an integrated practice teaching system for marketing major}

The integration of internal and external refers to the combination of external conditions and internal conditions, and then base on the actual situation of students to develop a targeted marketing professional teaching system, in which the main components include enterprises, schools, teachers, students, etc. The realization of the teaching system is to use the resources of social and school, to organic combine the theoretical teaching and practical teaching, in order to cultivate the application of marketing professionals.

\subsection{Establish practice training model for marketing major}

The establishment of a segmented, modular, and integrated marketing professional practice talent training model should in accordance with the actual needs of the talent market, so to realize the goal of practical teaching during apprenticeship and improve the professional knowledge theory and skills of students or apprentices, this model not only helps to strengthen the cultivation of students' practical ability, but also helps improve the marketing professional teaching and training quality and efficiency of enterprises and schools.

\subsection{Construct the curriculum system}

The determination of the marketing professional talent training objectives should be based on the knowledge and professional capabilities required for each position [3]. Based on a mission-oriented approach, and based on a relatively complete marketing industry chain, a technical skills curriculum system is constructed. Set the curriculum system as the core, the basic professional ability curriculum, professional core ability curriculum, and professional development ability curriculum are radiated outward. Taking the postgraduate internship and comprehensive technical skills training course as the supporting point, then develop the development-oriented, compound and innovative technical and technical talents. In the process of training, we should emphasize technology, and focus on skills, innovation, and humanities to achieve the comprehensive development.

In order to ensure the seamless integration of courses, marketing professionals should establish a linkage development mechanism between professional teaching standards and professional standards to prompt the updating of the teaching content, thus to meets the professional educational philosophy. Secondly, before the modern apprenticeship system is carried out, it is necessary to set up the system of the enterprise and the students' characteristics, the standard of the industry, and the exchange system of the enterprise practice and the curriculum credits, to establish the double standard assessment system for the academic standards and apprenticeship standards. We should not continue the traditional theoretical curriculum setting. Instead, it is necessary to set up a corresponding 
curriculum system based on the analysis of the company's talent requirements and professional skills through tripartite discussions and exchanges among school teachers, corporate masters, and industry experts. According to the vocational qualification requirements of the industry in which the company is located, it is included in the education curriculum, and students are encouraged to actively participate in industry-sponsored skill contests. In the course of the curriculum, it is necessary to reflect the promotion of subsection advanced courses, to meet the talent cultivation requirements.

\subsection{Innovate classroom teaching mode}

To make full use of information technology, the teachers can publish preparatory homework on the online platform such as Micro Lessons, Handheld Communication and create problem situations so that students can preview the course content and mobilize their enthusiasm and initiative in classroom learning [4]. In this participatory process, help student learn to think independently and teamwork sprit, so as to cultivate students' comprehensive ability and innovation ability.

\section{Summary}

The modern apprenticeship system has maximized the advantages of both companies and schools, and promoted the development of vocational education and deep school-enterprise cooperation. Compared with traditional apprenticeships, modern apprenticeships are more conducive to the improvement of students' practical ability, adaptability, learning ability and survivability, and could also cultivate talents that meet the requirements of the development of enterprises and society. The scientifically and rationally application of modern apprenticeship in marketing professional practice teaching can greatly shorten the transition time from school education to enterprise development and shorten the transition time for students to work. It is an important measure for schools and enterprises to cultivate high-practical ability marketing talents. Therefore, both schools and enterprises should apply modern apprenticeships to marketing professional teaching and apply them to the construction of marketing professional teaching systems, so as to improve the quality of marketing professional teaching.

\section{Acknowledgement}

The Research Project of Vocational Education Teaching Reform in Shandong Province, Reform and practice of Marketing Practice Teaching system based on Modern Apprenticeship system (subject No.: 2017501)

\section{References}

[1] Deng Dahui. Thoughts on the Reform of Modern Apprentice Talents Training Model in Vocational Colleges[J]. Gakuen,2015(8), p.13

[2] Chen Rongquan, Analysis and Construction Strategy of Marketing Practice Teaching Model Based on School-enterprise Cooperation[J], Market Observation, 2015(22), p.27

[3] Zhong Rong, Research on Modern Talent Cultivation Model of Apprenticeship-Taking Higher Vocational Marketing Major as an Example[J], Global Markets, 2016(5), p.65

[4] Lei Hu, Li Wanjin, The Transfer Path of Knowledge and Skills in Modern Apprenticeship System and Its Influencing Factors-Based on the Practice of Discrete Post Practice in Vocational Colleges[J], Vocational Education Forum, 2015(6), p.71 